\title{
Age Estimation by Telomeric Length Using Human (Homo sapiens) and Domestic Cat (Felis catus) Epidermis, Bone and Cartilage Samples was Found to be Ineffective
}

\section{Manthanee Kaewkool $^{1}$, Wannapimol Kriangwanich ${ }^{2,3}$, Kittisak Buddhachat $^{4,5}$, Siriwadee Chomdej ${ }^{5,6}$, Pasuk Mahakkanukrauh ${ }^{7,8}$, Piyamat Kongtueng ${ }^{9}$, and Korakot Nganvongpanit ${ }^{2,5,8^{*}}$}

\begin{abstract}
${ }^{1}$ Division of Forensic Science, Graduate School, Chiang Mai University, Chiang Mai 50200, Thailand

${ }^{2}$ Department of Veterinary Biosciences and Public Health, Faculty of Veterinary Medicine, Chiang Mai University, Chiang Mai 50100, Thailand

${ }^{3}$ Leibniz Institute for Farm Animal Biology, Wilhelm-Stahl-Allee 2, Dummerstorf, 18196 Germany

${ }^{4}$ Department of Biology, Faculty of Science, Nareusuan University, Phitsanulok 65000, Thailand

${ }^{5}$ Excellence Center in Veterinary Bioscience, Chiang Mai University, Chiang Mai 50100, Thailand

${ }^{6}$ Department of Biology, Faculty of Science, Chiang Mai University, Chiang Mai 50200, Thailand

${ }^{7}$ Department of Anatomy, Faculty of Medicine, Chiang Mai University, Chiang Mai 50200, Thailand

${ }^{8}$ Excellence Center in Osteology Research and Training Center, Chiang Mai University, Chiang Mai 50200, Thailand

${ }^{9}$ Central Laboratory, Faculty of Veterinary Medicine, Chiang Mai University, Chiang Mai 50100, Thailand
\end{abstract}

Corresponding author.E-mail: korakot.n@cmu.ac.th

https://doi.org/10.12982/CMUJNS.2020.0033

Received: November 4, 2019

Revised: November 28, 2019

Accepted: November 29, 2019

\section{ABSTRACT}

Age estimation using telomere length is an alternative tool that could facilitate the casework in forensic investigations. Although blood can be used in the measurement of telomere length in order to estimate chronological age and/or biological age, the use of blood does present certain potential limitations such as the possibility of infection, the influence of medication, chemicals or the level of stress a subject might have been exposed to, all of which can 
contribute to fluctuations in telomere length. In this study, tissue samples of the epidermis, bone, and cartilage were collected from human cadavers (Homo sapiens, $n=80$ ) and those of domestic cats (Felis catus, $n=30$ ) for telomere shortening assessment. The relative telomere length (RTL) was assessed by real-time PCR to estimate the age of the collected specimens ranking between 16- to 95- or 1- to 9-year old human or domestic cat cadavers, respectively. As a result, there was no significant correlation between telomere shortening and age recorded in the bone and cartilage, yet a small positive relationship between age and telomere shortening was observed in the human epidermis with $R^{2}=0.0276(p=0.0095)$ and in the epidermis samples obtained from female domestic cats with $R^{2}=0.1373(p=0.0171)$. Taken together, these results suggest that the determination of telomere length using real-time PCR obtained from human epidermis, bone, and cartilage samples may not be applicable for determination of an estimation of age in human and domestic cat specimens.

Keywords: Age, Bone, Cartilage, Skin, Telomere, Senescence

\section{INTRODUCTION}

The aging process, or senescence, is related to progressive and irreversible cellular changes that seem to function as a molecular clock. Most somatic cells have the capability of a limited number of divisions, which is the main cause for cell senescence (Allsopp et al., 1992; Blasco, 2005). One theory for this is that this cellular senescence is caused by a gradual decrease in the telomere length (Harley et al., 1990; Epel et al., 2004; Monaghan and Haussmann, 2006). Telomeres are comprised of repeating nucleotides (TTAGGG) that are located at the end of a chromosome. They play an important role in maintaining chromosome integrity which may be affected by deterioration or damage (Blackburn, 1991; Shay and Wright, 2000; Takasaki et al., 2003) Telomere length shortening occurs normally in most somatic cells during DNA replication throughout the lifespan of living organisms (McEachern et al., 2000; Cawthon, 2002; McKevitt et al., 2002; Haussmann et al., 2003; Vleck et al., 2003; Callicott and Womack, 2006; Hewakapuge et al., 2008; Izzo et al., 2011). Presently, telomere length has been widely used to estimate age in human subjects (Hewakapuge et al., 2008; Karlsson et al., 2008) and for several other mammalian species such as mice (Callicott and Womack, 2006), dogs (Nasir et al., 2001; McKevitt et al., 2002; Fick et al., 2012; Buddhachat et al., 2017), sea lions (Izzo et al., 2011) and elephants (Buddhachat et al., 2017). However, when the outcomes from several studies were compared, a degree of inconsistency was observed among the various subjects. Therefore, the correlations between telomere length and age could only be validated in some studies (Haussmann et al., 2003; Vleck et al., 2003), while the results were inconclusive in some other 
studies (McKevitt et al., 2002). Many previous studies have used blood as a source of DNA for the determination of telomeric attrition. Blood was used because it is relatively easy to collect blood samples from subjects, and blood can often be found at the scene where victims have died (Friedrich et al., 2000; Cawthon et al., 2003; Thomas et al., 2008; Dlouha et al., 2014; Goglin et al., 2016). However, white blood cells have a short life-span (1-3 days) (Dlouha et al., 2014), and there are many factors that can affect white blood cell division, such as infections (Shammas, 2011), the influence of medication or chemicals (Shammas, 2011), and the degree of stress a subject may have experienced (Epel et al., 2004; Shammas, 2011). For these reasons, the age estimation of telomeric attrition using other tissues may be a preferred way of supporting the information that has been obtained from white blood cells, and may also be a way to produce more reliable estimations of age. In accordance with a number of previously published studies, other tissues have been used to assess the relationship between age and telomere shortening, such as buccal (Hewakapuge et al., 2008; Thomas et al., 2008), brain tissue (Thomas et al., 2008), synovial tissue (Friedrich et al., 2000), skin (Friedrich et al., 2000), kidney tissue (Melk et al., 2000) or dental pulp (Takasaki et al., 2003). The degree of telomere shortening that occurs with age increases at different levels for the different tissues being studied (Table 1). Moreover, some tissues, such as those of the epidermis, appeared to present a contradicting result when compared to the findings of other studies. This was the case with regard to the increase in telomere length that was reported in a study undertaken by Buckingham and Klingelhutz (Buckingham and Klingelhutz, 2011), as well as in the findings from a study conducted by Sugimoto (Sugimoto et al., 2006).

Currently, there are three methods that are used to assess telomere length including southern blotting or terminal restriction fragments (TRFs) (Friedrich et al., 2000; Melk et al., 2000; Haussmann et al., 2003; Vleck et al., 2003; Aviv et al., 2011), flow fluorescence in situ hybridization (FISH) (Canela et al., 2007) and the quantitative PCR (qPCR) method (Cawthon, 2002; Callicott and Womack, 2006; Hewakapuge et al., 2008; Izzo et al., 2011; Goglin et al., 2016). In this study, we used a qPCR-based technique to examine the shortening of human and domestic cat telomere lengths in three different tissue samples including bone, cartilage and epidermis specimens that were obtained from human and cat subjects. We hypothesize that the shortening of these tissue telomere lengths will occur along with an increase in the age of the subject. 
Table 1. Telomere shortening in human tissue.

\begin{tabular}{lll}
\hline $\begin{array}{l}\text { Reduction rate } \\
\text { (bp/year) }\end{array}$ & Tissue & References \\
\hline$<20$ & $\begin{array}{l}\text { fibroblast, renal medulla, } \\
\text { epidermal and dermal tissue }\end{array}$ & $\begin{array}{l}\text { (Allsopp et al., 1992; } \\
\text { Melk et al., 2000; } \\
\text { Sugimoto et al., 2006) }\end{array}$ \\
$21-40$ & $\begin{array}{l}\text { blood, endothelium, renal cortex, spleen, } \\
\text { lingual mucosa and pancreas }\end{array}$ & $\begin{array}{l}\text { (Hastie et al., 1990; } \\
\text { Slagboom et al., 1994; Melk } \\
\text { et al., 2000; Nakamura et al., }\end{array}$ \\
& & 2002; Takubo et al., 2002; \\
& & Ishii et al., 2006) \\
& & (Vaziri et al., 1993; \\
$41-60$ & lymphocyte, large and small & Hiyama et al., 1996; \\
& intestine, esophageal mucosa, liver, & Takubo K., 1999; \\
& colonic and gastric mucosa & Furugori et al., 2000; \\
& & Nakamura et al., 2000; \\
& & Takubo et al., 2000) \\
& & (Takasaki et al., 2003) \\
$61-80$ & dental pulp & (Kammori et al., 2002) \\
\hline 81 & thyroid and parathyroid gland & \\
\hline
\end{tabular}

\section{MATERIALS AND METHODS}

\section{Samples}

A total of 80 fresh human cadavers (female $=29$, male $=51$ ) ranging in age from 16 to 95 years (Figure 1A) were obtained from the Cadaveric Surgical Training Center, Department of Anatomy, Faculty of Medicine, Chiang Mai University. All 80 subjects were human and died in Chiang Mai Province, which is located in the north of Thailand; however, the subjects had originated from ten different hometowns within the province (Figure 1B). The number of samples used in this study was determined based on the squared multiple correlation coefficient $\left(\mathrm{R}^{2}\right)$, wherein 0.3 indicates a positive prediction level according to the study conducted by Knofczynski and Mundfrom (2008). Domestic cat cadavers were obtained from the Veterinary Cadaveric Center, Faculty of Veterinary Medicine, Chiang Mai University. A total 30 cadavers (female $=15$, male=15) ranging in age from 1 to 9 years were included in this study. 

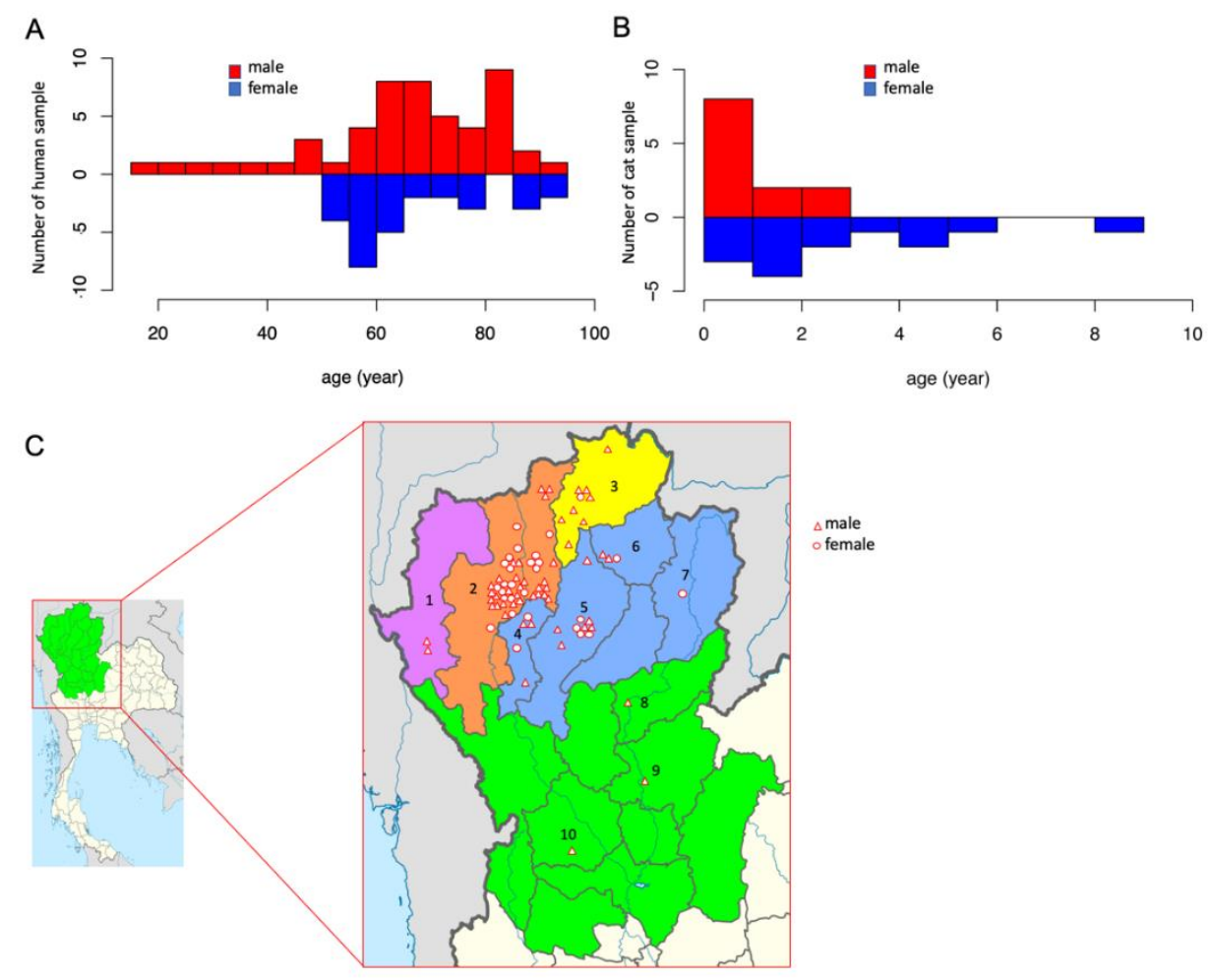

Figure 1. Human and cat populations by region for the subjects investigated in this study. The numbers of male and female subjects among humans were 51 and 29, and in cats, they were 15 and 15, respectively. The age of the subjects ranged from 16 to 95 years in humans (A) and 1 to 9 years in cat (B). The geographic hometowns of the humans (C) in this study were as following: 1=Mae Hong Son $(n=2), 2=$ Chiang Mai $(\mathrm{n}=47), 3=$ Chiang Rai $(\mathrm{n}=9)$, 4=Lamphun $(\mathrm{n}=5), 5=$ Lampang $(\mathrm{n}=10)$, $6=$ Phayao $(n=3), 7=$ Nan $(n=1), 8=$ Uttaradit $(n=1), 9=$ Phitsanulok $(\mathrm{n}=1), 10=$ Kamphaeng Phet $(\mathrm{n}=1)$.

The smallest right toe of human subjects and the right $5^{\text {th }}$ phalanx of domestic cat subjects were taken from each cadaver for tissue collection. Tissue samples were comprised of epidermis (ventral part of little toe), cartilage (articular cartilage between middle and distal phalanx) and bone (distal phalanx) material. The toes were washed twice with $5 \%$ chloroxylenol (Dettol ${ }^{\circledR}$, Thailand) for 10 min followed by being soaked in phosphate buffered saline (PBS) plus penicillin, streptomycin and amphotericin B $\left(\mathrm{Gibco}^{\mathrm{TM}}\right.$ Antibiotic-Antimycotic, ThermoFisher, USA) for $5 \mathrm{~min}$ each. Each sample after being dissected into small pieces was kept in a microcentrifuge tube at $-20^{\circ} \mathrm{C}$ for DNA extraction. This study was approved by the Human Ethics Committee, Faculty of Medicine, Chiang Mai University, Thailand in 2018 (6593(8).3/16 March 2018). 


\section{DNA extraction and realtime PCR}

Tissue samples were extracted from the smallest right toe of each human cadaver and the right $5^{\text {th }}$ phalanx of each domestic cat cadaver according to the manufacturer's instructions included in the genomic DNA Extraction kits (RBC Bioscience, Taiwan). DNA was measured quantitatively using agarose gel electrophoresis, and absorbance was recorded at A260 for $50 \mathrm{ng} / \mu \mathrm{l}$ of stock DNA. Subsequently, DNA (50 ng) was used for the estimation of telomere length of each subject by qPCR as described by Cawthon (2002). Briefly, the final concentrations of the reagents in the PCR were 1x realtime master mix (Bioline, England) containing telomere primer concentrations of $270 \mathrm{nM}$ of tel 1 as follows: GGTTTTTGAGGGTGAGGGTGAGGGTGAGGGTGAGGGT, and $900 \mathrm{nM}$ of tel 2: TCCCGACTATCCCTATCCCTATCCCTATCTATCCCTA in a total volume of $10 \mu \mathrm{l}$. Additionally, the final 36B4 (single copy gene) primer concentration values were $400 \mathrm{nM}$ of forward: CAGAGTGAYGTG CAGCTGAT and of reverse: AAGCACTTCAGGGTTGTAGATGCTGCC. The cycling profile for the telomere (T) PCR was as follows: 40 cycles of $95^{\circ} \mathrm{C}$ for $15 \mathrm{~s}$ and $65^{\circ} \mathrm{C}$ for $2 \mathrm{~min}$. For 36B4 as single copy gene (S), profiles of 30 cycles of $95^{\circ} \mathrm{C}$ for $15 \mathrm{~s}$ and $68^{\circ} \mathrm{C}$ for $1 \mathrm{~min}$ were applied. After that, cycle threshold $\left(\mathrm{C}_{\mathrm{t}}\right)$ values were acquired from $\mathrm{qPCR}$ and used to calculate the relative telomere length (RTL). The RTL was derived from the following formula: $2^{\text {-delta(ct(telomere)-ct(36B4 gene)) }}$ and was expressed as telomere/single copy of gene (T/S). The rate of telomere loss was obtained from 1/slope of the linear regression model (RTL/year).

\section{Statistical analysis}

Differences in RTL among male and female subjects were determined using the Student's T-test. Correlations between relative telomere length and age were determined by using a linear regression model in the $\mathrm{R}$ program. The rate of telomere loss/increase was determined by the slope of the linear regression model and was expressed as RTL/year. The differences observed in terms of RTL in comparisons of the tissues in the same age group were determined by one-way analysis of variance (ANOVA). A significant difference was considered when $P<0.05$.

\section{RESULTS}

In the present study, the telomere length of three different tissue samples, including epidermis, cartilage, and bone tissue specimens that were obtained from the smallest toes of 80 human and 30 cat cadavers, was measured using qPCR. A correlation of telomere length and an increase in age was not observed except in the epidermis (Figure 2). Notably, in the epidermis, a small positive linearity of correlation was observed between telomere length and an increase in age 
$\left(\mathrm{R}^{2}=0.0276 ; P=0.0095\right)$ (Table 2). The equation of the linear regression was $\mathrm{Y}=275.229 * \mathrm{TS}+63.038 ; P<0.05$, and the increased rate of telomere length was $0.0036 \mathrm{TS} /$ year. When considering only the male subjects, we found that a significant increase in RTL was observed in the epidermis tissue, while RTL was not found to be correlated with age in the cartilage and bone tissue samples $(P>0.05)$ (Figure 2, Table 2). For the female subjects, a correlation was not observed between RTL and aging among the three samples of tissue.

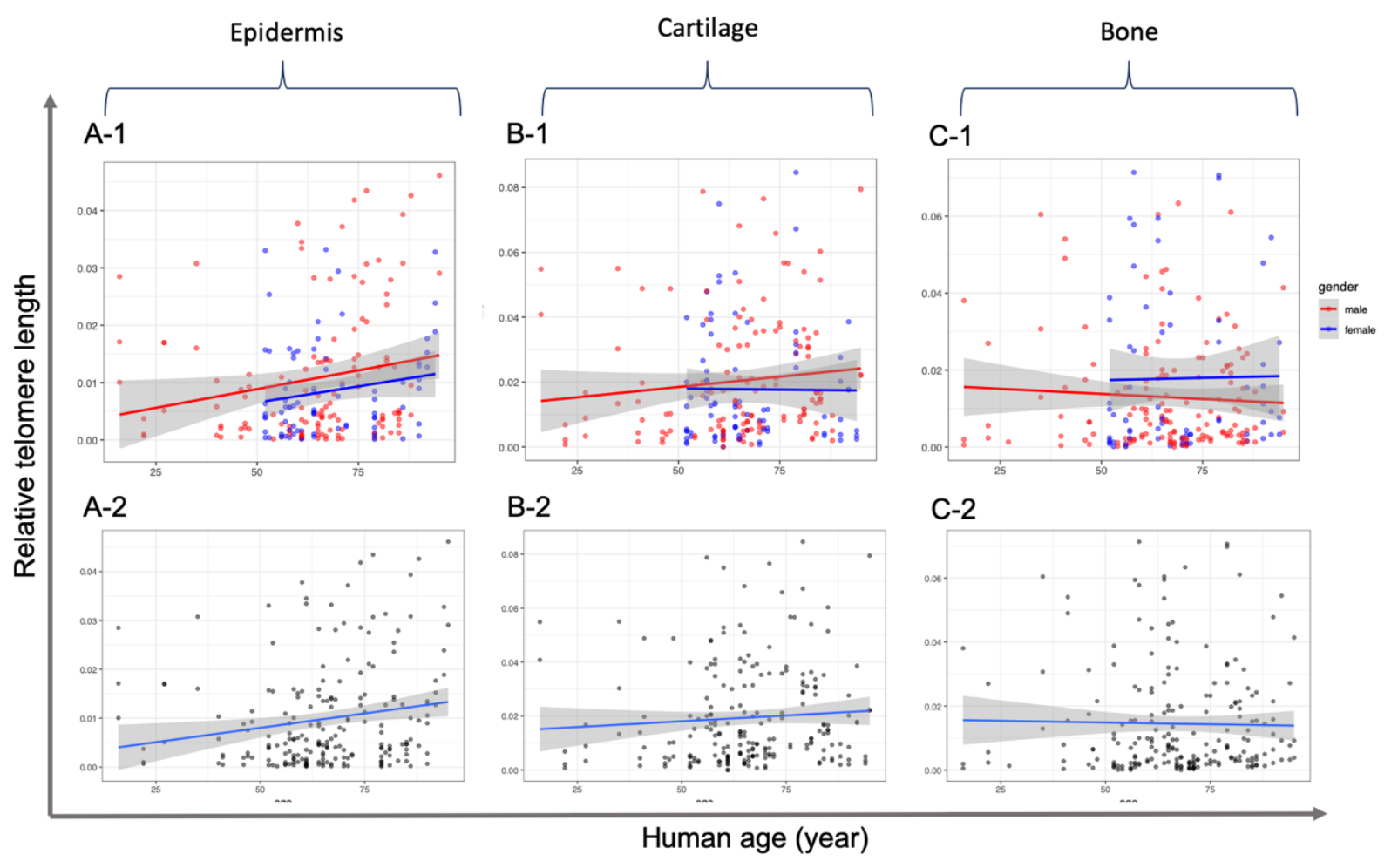

Figure 2. Correlation of relative telomere length and age from epidermis (A), cartilage (B) and bone (C) tissue samples of human subjects using realtime quantitative PCR. Data include relative telomere length in which the $\mathrm{C}_{\mathrm{t}}$ of telomere region $(\mathrm{T})$ was normalized by that of $36 \mathrm{~B} 4$ gene as a single copy gene. Linear regression and 95\% confidence intervals are shown as dashed lines with grey shading. The graphs are presented according to separated (-1) and merged (-2) gender.

In domestic cats, no correlation was found between telomere shortening and age in all three tissue samples (Figure 3). However, in consideration of only the female epidermis, a small positive linearity of correlation was observed between telomere length and an increase in ageing in animals $\left(\mathrm{R}^{2}=0.1373\right.$; $P=0.0171$ ) (Table 3). 
Table 2. Summary of the relationship between human telomere length for each tissue and age range.

\begin{tabular}{|l|l|l|l|l|l|l|l|l|l|}
\hline \multirow{2}{*}{ Parameter } & \multicolumn{3}{|c|}{ All (n=80) } & \multicolumn{3}{c|}{ Male (n=51) } & \multicolumn{3}{c|}{ Female (n=29) } \\
\hline & Epi. & Car. & Bo. & Epi. & Car. & Bo. & Epi. & Car. & Bo. \\
\hline $\begin{array}{l}{ }^{1} \text { Adjusted } \\
\mathrm{R}^{2}\end{array}$ & 0.0276 & 0.0006 & -0.0043 & 0.3123 & 0.0062 & -0.0032 & 0.0201 & -0.0127 & -0.0154 \\
\hline $\mathrm{R}^{2}$ & & & & & & & & & \\
\hline$P$-value & $\mathbf{0 . 0 0 9 5}$ & 0.2886 & 0.7682 & $\mathbf{0 . 0 2 6 7}$ & 0.1773 & 0.4655 & 0.1078 & 0.9311 & 0.8972 \\
\hline
\end{tabular}

Note: Bo. = bone, Car. = cartilage, Epi $=$ epidermis, $\mathrm{RTL}=$ relative telomere length, ${ }^{1}$ Adjustment of $\mathrm{R}^{2}$ based on the number of variables in the model.

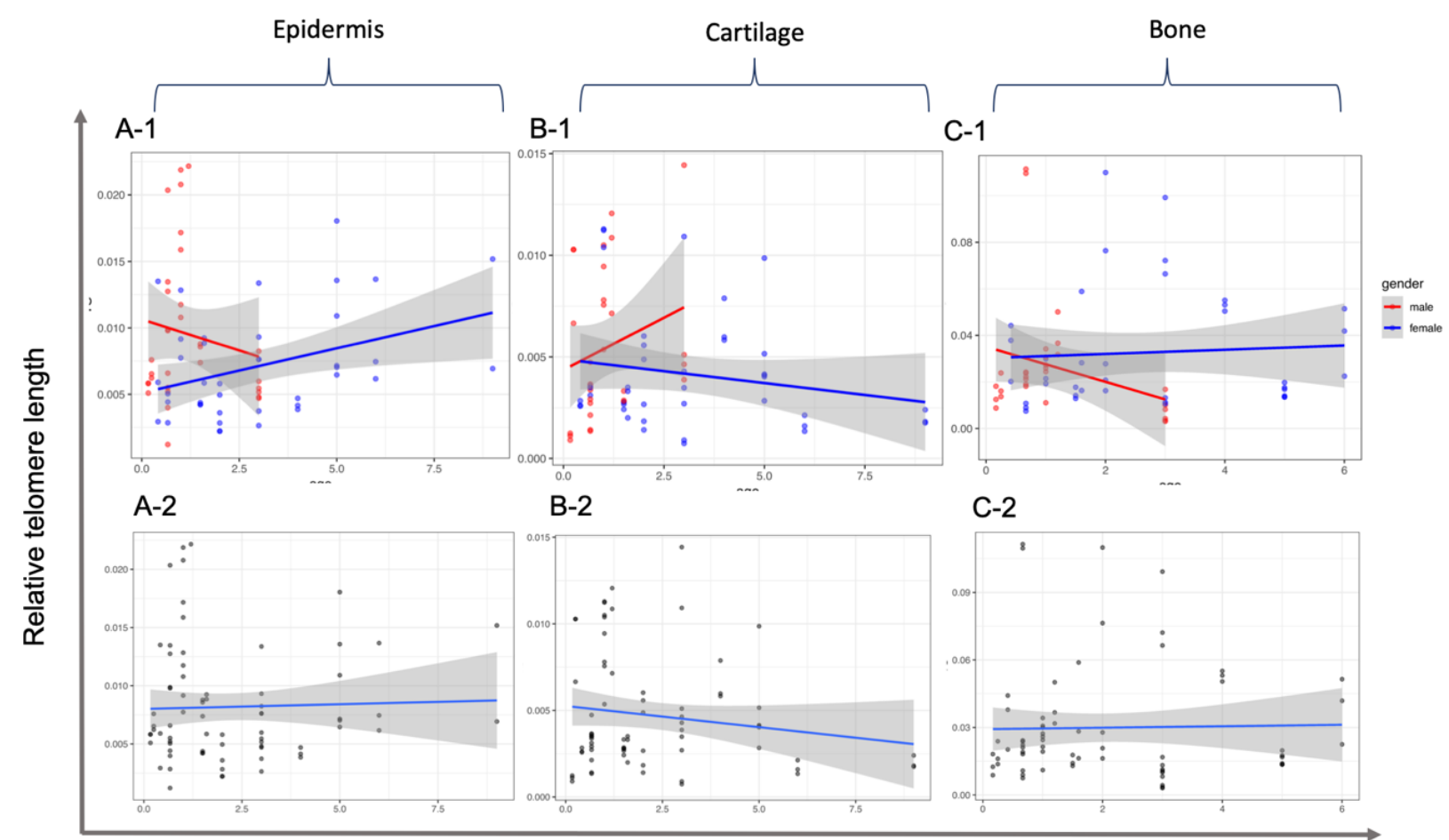

Cat age (year)

Figure 3. Correlation of relative telomere length and age from epidermis (A), cartilage (B) and bone (C) tissue samples of feline subjects using real-time quantitative PCR. Data include relative telomere length in which the $\mathrm{C}_{\mathrm{t}}$ of the telomere region (T) was normalized by that of $36 \mathrm{~B} 4$ gene as a single copy gene. Linear regression and $95 \%$ confidence intervals are shown as dashed lines with grey shading. The graphs are presented according to separated (-1) and merged (-2) gender.

The RTL values obtained from human epidermis, cartilage and bone tissues were not different among the male and female subjects (Figure 4), for which $P$-values were recorded at $0.117,0.319$ and 0.091 , respectively. However, RTL values obtained from the epidermis of male domestic cats were significantly 
$(P=0.046)$ higher than those of the female subjects, while cartilage $(P=0.1102)$ and bone $(P=0.3126)$ tissues were not observed to be different in a comparison of sexes.

Table 3. Summary of the relationship between feline telomere length for each tissue and age range.

\begin{tabular}{|l|l|l|l|l|l|l|l|l|l|}
\hline Parameter & \multicolumn{3}{|c|}{ All (n=30) } & \multicolumn{3}{c|}{ Male (n=15) } & \multicolumn{3}{c|}{ Female (n=15) } \\
\hline & Epi. & Car. & Bo. & Epi. & Car. & Bo. & Epi. & Car. & Bo. \\
\hline${ }^{1}$ Adjusted & -0.013 & 0.0110 & -0.0149 & -0.0074 & 0.0222 & 0.0521 & $\mathbf{0 . 1 1 5 2}$ & 0.0124 & -0.0238 \\
& & & & & & & & & \\
$\mathrm{R}^{2}$ & 0.0011 & 0.0250 & 0.0004 & 0.0251 & 0.0559 & 0.0859 & $\mathbf{0 . 1 3 7 3}$ & 0.0365 & 0.0040 \\
\hline$P$-value & 0.784 & 0.1849 & 0.8653 & 0.3865 & 0.2085 & 0.1228 & $\mathbf{0 . 0 1 7 1}$ & 0.2255 & 0.7093 \\
\hline
\end{tabular}

Note: Bo. = bone, Car. = cartilage, Epi $=$ epidermis, $\mathrm{RTL}=$ relative telomere length, ${ }^{1}$ Adjustment of $\mathrm{R}^{2}$ based on the number of variables in the model.
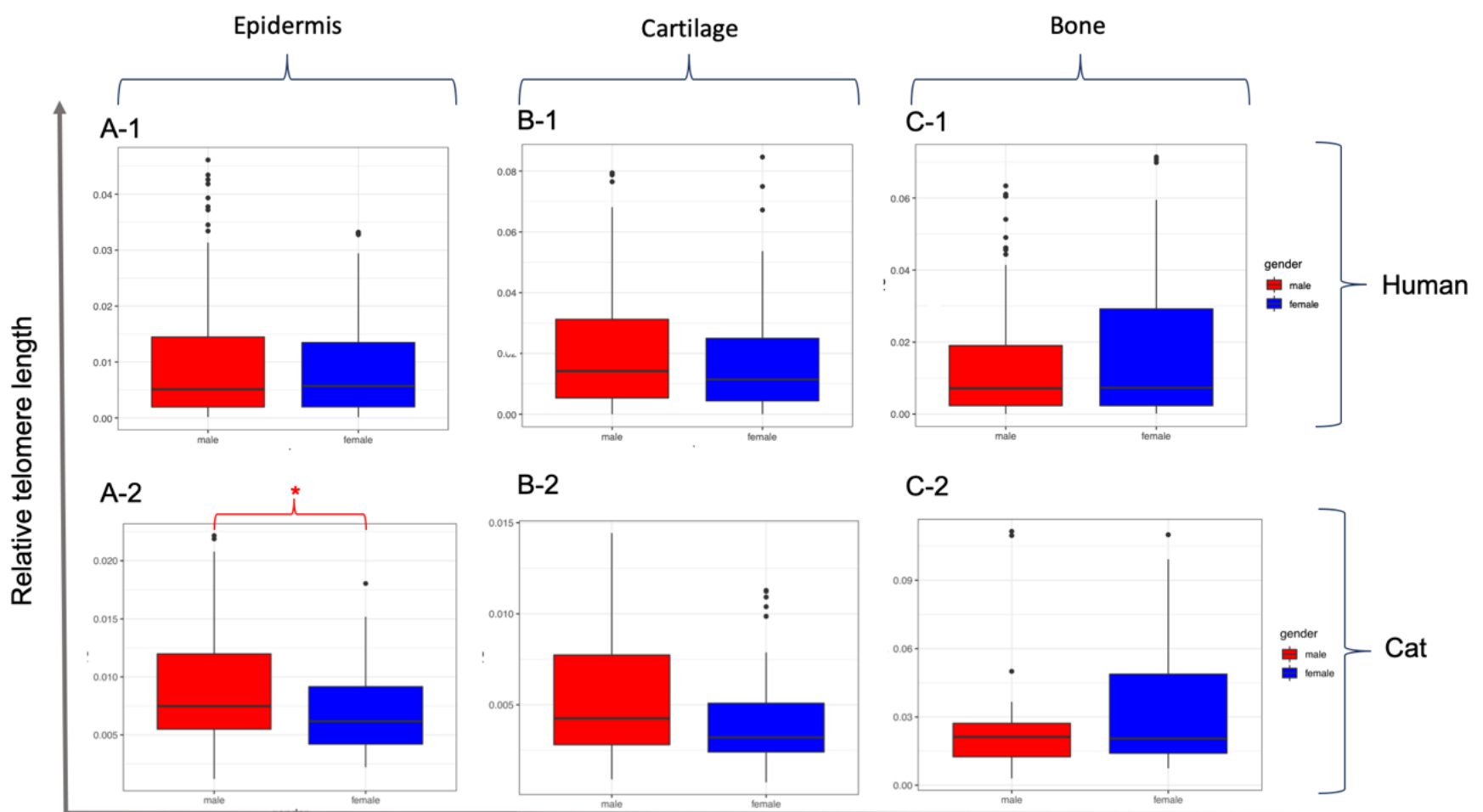

B-2

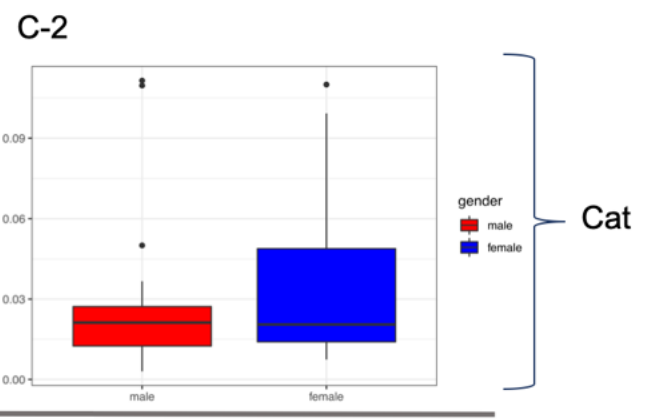

Gender

Figure 4. Comparison of relative telomere length from epidermis (A), cartilage (B) and bone (C) tissue samples in humans (-1) and cats (-2) among male and female subjects. Box plots present the median value of $25 \%$, and $75 \%$ confidence intervals, along with the non-outlier minimum and maximum whiskers. The * indicates a significant difference $(P<0.05)$ between genders. 


\section{DISCUSSION}

Although there have been several studies on the relationship between telomere shortening and age in humans, no study has been reported involving domestic cats. Based on our knowledge and the relevant literature review, this is the first study that has measured telomere length in human cartilage and bone tissue samples in order to investigate the presence of a correlation between telomere length and age. The major findings identified in this present study were;

1) The RTL was not correlated with age in the cartilage and bone tissue samples obtained from both humans and cats.

2) The RTL values obtained from the epidermis tissue were significantly increased with age in both humans and cats.

3) The RTL values obtained from the three samples of tissue were not different in comparisons of gender in humans, but this was not the case in the epidermal tissue of domestic cats.

These results suggest that telomere length did not decrease in all tissue samples as humans and cats aged. In using the shortening of telomere length as a tool to estimate the age of humans and cats, the type of sample used must be considered.

Previous studies on the senescence mechanisms of bone tissues focused on the alterations of signaling molecules (Marie, 2014), while the telomere length of bone tissue has been associated with some diseases such as osteoporosis (Valdes et al., 2007; Pignolo et al., 2008; Sanders et al., 2009; Tang et al., 2010; Herrmann et al., 2018). In 2007, the telomere length was measured in a total of 2,150 human female subjects that had been diagnosed with osteoporosis and shorter leukocyte telomere lengths were observed (Valdes et al., 2007). However, other studies reported that the shorter leukocyte telomere lengths revealed no correlation with osteoporosis (Pignolo et al., 2008; Sanders et al., 2009; Tang et al., 2010). However, the shortcoming of those studies was that telomere length was not detected directly from bone tissue; instead, the leukocyte telomere lengths that were measured within the bone were used. Our study revealed that no correlation was observed between the telomere length in the cells of bone tissue samples and that the age of the subject could be detectable. In general, bone tissue samples can be comprised of three types of cells; predominate with osteocyte followed by osteoblast and a small amount of osteoclast (Marie, 2014). The osteoblast and osteoclast found in bone tissue are mature cells that no longer divide. Osteocytes are caused by the differentiation of osteoblasts that originate from mesenchymal stem cells (MSC). Thus, it is plausible to suggest that the telomere shortening observed in the bone tissue could be slightly reduced when compared to other tissues. 
We believe that a possible explanation for this is that the telomere length in the cartilage did not decrease with age when compared with the tissue of the bone. Cartilage tissue samples consisted of two cell types; predominate with chondrocyte and a small amount of chondroblasts, as well as chondrocytes that were directly derived from chondroblasts obtained from MSC (Carballo et al., 2017). It has been well-established that cell proliferations of chondrocytes have hardly ever occurred when they reach maturity. This phenomenon leads to a slow down or absence in cartilage recovery when an individual gets injured (Martin and Buckwalter, 2001a; Toh et al., 2016). Signs of cartilage cell senescence in vivo include; decreases in the population of chondrocyte cells ( Barbero et al., 2004; Adkisson et al., 2010) and a decrease in the degree of proteoglycan synthesis (Martin and Buckwalter, 2001a; Pestka et al., 2011). Up until now, telomere shortening in the cartilage has been reported only in the chondrocyte culture in vitro indicating that a decrease in telomere length occurs during the sub-culturing stage (Toh et al., 2016; López-Alcorocho et al., 2019). However, some studies have reported that no correlation exists between the telomere length of healthy subjects and those with severe osteoarthritis cartilage damage (Martin and Buckwalter, 2001b; Rose et al., 2012).

Previous studies have revealed contradicting results regarding the relationship between telomere length and age in epidermal tissue samples (Taylor et al., 1996; Ueda et al., 1997; Sugimoto et al., 2006; Krunic et al., 2009; Buckingham and Klingelhutz, 2011). One possible explanation for this is that telomere length can increase in epidermal cells in the presence of the telomerase enzyme complex, contributing to the maintenance of telomere length; however, this is almost undetectable in the dermis tissue (Buckingham and Klingelhutz, 2011). In addition, the exposure of the epidermis to ultraviolet (UV) rays would trigger telomerase activity (Taylor et al., 1996; Ueda et al., 1997; Stout and Blasco, 2013). Thus, environmental factors, in particular exposure to UV light, can account for the cause of certain variations in the telomere length of the epidermis. In conclusion, we suggest that it may be inappropriate to use telomere length in tissue samples obtained from the epidermis to estimate age using qPCR.

Gender differences are one of the factors associated with telomere attrition in mammalian species because of certain heterogametic influences. This can account for some of the observed sex-bias differences that have been reported in investigations of mortality (Barrett and Richardson, 2011). The average telomere length in females was higher and telomere length attrition was less than that of males (Mayer et al., 2006). However, our findings did not find any differences in the RTL of all three tissue samples in a comparison of male and female subjects. It is possible that the individuals of both genders from which the samples were obtained were quite old (over 50 years). Thus, samples should be obtained from individuals of roughly the same age, and preferably from newborns or children, 
in order to reduce/control the influence of some of the other factors that are associated with age.

\section{CONCLUSION}

Understanding the correlation between telomere length and senescence could potentially help in estimating age among humans and some mammal species. However, in our study, there was no correlation observed between telomere shortening and aging in the cartilage and bone tissue samples except in the tissue of the epidermis. Notably, a positive correlation was observed between telomere length and aging in the epidermis tissue of humans, but not in cats. Thus, we believe that the effective use of these three tissues as a forensic tool for age estimation appears to be limited.

\section{ACKNOWLEDGEMENTS}

The authors are grateful for the research funding provided by the Excellence Center in Osteology Research and Training Center and the Excellence Center in Veterinary Bioscience, Chiang Mai University, Chiang Mai, Thailand.

\section{REFERENCES}

Adkisson, H.D., Martin, J.A., Amendola, R.L., Milliman, C., Mauch, K.A., Katwal, A.B., Seyedin, M., Amendola, A., Streeter, P.R., and Buckwalter, J.A. 2010. The potential of human allogeneic juvenile chondrocytes for restoration of articularcartilage. American Journal of Sports Medicine. 38(7): 1324-1333. https://doi.org/10.1177/0363546510361950

Allsopp, R.C., Vaziri, H., Patterson, C., Goldstein, S., Younglai, E.V., Futcher, A.B., Greider, C.W., and Harley, C.B., 1992. Telomere length predicts replicative capacity of human fibroblasts. Proceedings of the National Academy of Sciences. USA. 89(21): 10114-10118. https://doi.org/10.1073/ pnas.89.21.10114

Aviv, A., Hunt, S.C., Lin, J., Cao, X., Kimura, M., and Blackburn, E. 2011. Impartial comparative analysis of measurement of leukocyte telomere length/DNA content by Southern blots and qPCR. Nucleic Acids Research. 39(20):e134 . https://doi.org/10.1093/nar/gkr634

Barbero, A., Grogan, S., Schäfer, D., Heberer, M., Mainil-Varlet, P., and Martin, I. 2004. Age related changes in human articular chondrocyte yield, proliferation and post-expansion chondrogenic capacity. Osteoarthritis Cartilage. 12(6): 476-484. https://doi.org/10.1016/j.joca.2004.02.010

Barrett, E.L., and Richardson, D.S. 2011. Sex differences in telomeres and lifespan. Aging Cell. 10(6): 913-921. https://doi.org/10.1111/j.1474-9726.2011. 00741.x 
Blackburn, E.H. 1991. Structure and function of telomeres. Nature. 350: 569-573. https://doi.org/10.1038/350569a0

Blasco, M.A. 2005. Telomeres and human disease: ageing, cancer and beyond. Nature Reviews Genetics. 6(8): 611-622. https//doi.org/10.1038/nrg1656

Buckingham, E.M., and Klingelhutz, A.J. 2011. The role of telomeres in the ageing of human skin. Experimental Dermatology. 20(4): 297-302. https://doi.org/ 10.1111/j.1600-0625.2010.01242.x

Buddhachat, K., Kriangwanich, W., Kumoun, I., Brown, J.L., Chailangkarn, S., Somgird, C., Thitaram, C., Prasitwattanaseree, S., and Nganvongpanit, K. 2017. Telomeric attrition with increasing age in short- (Chihuahua Dog) and long- (Asian Elephant) life span animals. Kafkas Üniversitesi Veteriner Fakültesi Dergisi. 23(4): 643-649. https://doi.org/10.9775/kvfd.2017.17504

Callicott, R.J., and Womack, J.E. 2006. Real-time PCR assay for measurement of mouse telomeres. Comparative Medicine. 56(1): 17-22.

Canela, A., Vera, E., Klatt, P., and Blasco, M.A. 2007. High-throughput telomere length quantification by FISH and its application to human population studies. Proceeding of the National Academy of Sciences of the United States of America. 104(13): 5300-5305. https://doi.org/10.1073/pnas.0609367104

Carballo, C.B., Nakagawa, Y., Sekiya, I., and Rodeo, S.A. 2017. Basic science of articular cartilage. Clinics in Sports Medicine. 36(3): 413-425. https://doi.org/ 10.1016/j.csm.2017.02.001

Cawthon, R.M. 2002. Telomere measurement by quantitative PCR. Nucleic Acids Research. 30(10): e47. https://doi.org/10.1093/nar/30.10.e47

Cawthon, R.M., Smith, K.R., O'Brien, E., Sivatchenko, A., and Kerber, R.A. 2003. Association between telomere length in blood and mortality in people aged 60 years or older. Lancet. 361(9355): 393-395. https://doi.org/ 10.1016/S01406736(03)12384-7

Dlouha, D., Maluskova, J., Kralova Lesna, I., Lanska, V., and Hubacek, J.A. 2014. Comparison of the relative telomere length measured in leukocytes and eleven different human tissues. Physiological Research. 63: S343-S350.

Epel, E.S., Blackburn, E.H., Lin, J., Dhabhar, F.S., Adler, N.E., Morrow, J.D., and Cawthon, R.M. 2004. Accelerated telomere shortening in response to life stress. Proceeding of the National Academy of Sciences of the United States of America. 101(49): 17312-17315. https://doi.org/10.1073/pnas.0407162101

Fick, L.J., Fick, G.H., Li, Z., Cao, E., Bao, B., Heffelfinger, D., Parker, H.G., Ostrander, E.A., and Riabowol, K. 2012. Telomere length correlates with life span of dog breeds. Cell Reports. 2(6): 1530-1536. https://doi.org/ 10.1016/ j.celrep.2012.11.021

Friedrich, U., Griese, E., Schwab, M., Fritz, P., Thon, K., and Klotz, U. 2000 Telomere length in different tissues of elderly patients. Mechanisms of Ageing and Development. 119(3): 89-99. https://doi.org/10.1016/ s0047-6374(00)00173-1 
Furugori, E., Hirayama, R., Nakamura, K.I., Kammori, M., Esaki, Y., and Takubo, K. 2000. Telomere shortening in gastric carcinoma with aging despite telomerase activation. Journal of Cancer Research and Clinical Oncology. 126: 481-485. https://doi.org/10.1007/s004320000137

Goglin, S.E., Farzaneh-Far, R., Epel, E.S., Lin, J., Blackburn, E.H., and Whooley, M.A. 2016. Change in leukocyte telomere length predicts mortality in patients with stable coronary heart disease from the heart and soul study. PLoS ONE. 11(10): 1-12. https://doi.org/10.1371/journal. pone. 0160748

Harley, C.B., Futcher, A.B., and Greider, C.W. 1990. Telomeres shorten during ageing of human fibroblasts. Nature. 345(6274): 458-460. https://doi.org/ $10.1038 / 345458 \mathrm{a} 0$

Hastie, N.D., Dempster, M., Dunlop, M.G., Thompson, A.M., Green, D.K., and Allshire, R.C. 1990. Telomere reduction in human colorectal carcinoma and with ageing. Nature. 346(6287): 866-868. https://doi.org/10.1038/ 346866a0

Haussmann, M.F., Vleck, C.M., and Nisbet, I.C. 2003. Calibrating the telomere clock in common terns, Sterna hirundo. Experimental Gerontology. 38(7): 787-789. https://doi.org/10.1016/s0531-5565(03)00109-8

Herrmann, M., Pusceddu, I., Marz, W., and Herrmann, W. 2018. Telomere biology and age-related disease. Clinical Chemistry and Laboratory Medicine. 56(8): 1210-1222. https://doi.org/10.1515/cclm-2017-0870

Hewakapuge, S., van Oorschot, R.A., Lewandowski, P., and Baindur-Hudson, S. 2008. Investigation of telomere lengths measurement by quantitative real-time PCR to predict age. Leg Med (Tokyo). 10(5): 236-242. https://doi.org/ 10.1016/j.legalmed.2008.01.007

Hiyama, E., Tatsumoto, N., Kodama, T., Hiyama, K., Shay, J., and Yokoyama, T. 1996. Telomerase activity in human intestine. International Journal of Oncology. 9: 453-458. https://doi.org/10.3892/ijo.9.3.453

Ishii, A., Nakamura, K., Kishimoto, H., Honma, N., Aida, J., Sawabe, M., Arai, T., Fujiwara, M., Takeuchi, F., Kato, M., Oshimura, et al. 2006. Telomere shortening with aging in the human pancreas. Experimental Gerontology. 41(9): 882-886. https://doi.org/10. 1016/j.exger.2006.06.036

Izzo, C., Hamer, D.J., Bertozzi, T., Donnellan, S.C., and Gillanders, B.M. 2011. Telomere length and age in pinnipeds: The endangered Australian sea lion as a case study. Marine Mammal Science 27: 841-851. https://doi.org/10. 1111/j.1748-7692.2010.00450.x

Kammori, M., Nakamura, K.I., Kawahara, M., Mimura, Y., Kaminishi, M., and Takubo, K. 2002. Telomere shortening with aging in human thyroid and parathyroid tissue. Experimental Gerontology. 37(4): 513-521. https:// doi.org/10.1016/s0531-5565(01)00178-4 
Karlsson, A.O., Svensson, A., Marklund, A., and Holmlund, G. 2008. Estimating human age in forensic samples by analysis of telomere repeats. Forensic Science International 1: 569-571. https://doi.org/10.1016/j.fsigss.2007.10. 153

Knofczynski, G.T., and Mundfrom, D. 2007. Sample sizes when using multiple linear regression for prediction. Educational and Psychological Measurement. 68: 431-442. https://doi.org/10.1177/0013164407310131

Krunic, D., Moshir, S., Greulich-Bode, K.M., Figueroa, R., Cerezo, A., Stammer, H., Stark, H.J., Gray, S.G., Nielsen, K.V., Hartschuh, W., et al. 2009. Tissue context-activated telomerase in human epidermis correlates with little age-dependent telomere loss. Biochimica et Biophysica Acta. 1792(4): 297-308. https://doi.org/10.1016/j.bbadis.2009.02.005

López-Alcorocho, J.M., Guillén-Vicente, I., Rodríguez-Iñigo, E., Guillén-Vicente, M., Fernández-Jaén, T.F., Caballero, R., Casqueiro, M., Najarro, P., Abelow, S., and Guillén-García, P. 2019. Study of telomere length in preimplanted cultured chondrocytes. Cartilage. 10(1): 36-42. https://doi.org/10.1177/1947603517749918

Marie, P.J. 2014. Bone cell senescence: mechanisms and perspectives. Journal of Bone and Mineral Research. 29(6): 1311-1321. https://doi.org/10.1002/ jbmr.2190

Martin, J.A., and Buckwalter, J.A. 2001a. Roles of articular cartilage aging and chondrocytesenescence in the pathogenesis of osteoarthritis. The Iowa Orthopaedic Journal. 21: 1-7.

Martin, J.A., and Buckwalter, J.A. 2001b. Telomere erosion and senescence in human articular cartilage chondrocytes. The Journals of Gerontology. Series A, Biological Sciences and Medical Sciences. 56(4): 172-179. https://doi.org/10.1093/gerona/56.4.b172

Mayer, S., Bruderlein, S., Perner, S., Waibel, I., Holdenried, A., Clioglu, N., Hasel, C., Mettfeldt, T., Nielsen, K.V., and Moller, P. 2006. Sex-specific telomere length profiles and age-dependent erosion dynamics of individual chromosome arms in humans. Cytogenetic and Genome Research. 112 (3-4): 194-201. https://doi.org/10.1159/000089870

McEachern, M.J., Krauskopf, A., and Blackburn, E.H. 2000. Telomeres and their control. Annual Review of Genetics. 34: 331-358. https://doi.org/10.1146/ annurev.genet.34.1.331

McKevitt, T.P., Nasir, L., Devlin, P., and Argyle, D.J. 2002. Telomere lengths in dogs decrease with increasing donor age. Journal of Nutrition.132: 1-3. https://doi.org/10.1093/jn/132.6.1604S

Melk, A., Ramassar, V., Helms, L.M., Moore, R., Rayner, D., Solez, K., and Halloran, P.F. 2000. Telomere shortening in kidneys with age. Journal of the American Society of Nephrology. 11(3): 444-453. 
Monaghan, P., and Haussmann, M.F. 2006. Do telomere dynamics link lifestyle and lifespan? Trends in Ecology \& Evolution. 21(1): 47-53. https://doi.org/ 10.1016//j.tree.2005.11.007

Nakamura, K., Furugori, E., Esaki, Y., Arai, T., Sawabe, M., Okayasu, I., Fujiwara, M., Kammori, M., Mafune, K., Kato, M., et al. 2000. Correlation of telomere lengths in normal and cancers tissue in the large bowel. Cancer Letters. 158(2): 179-184. https://doi.org/10.1016/s0304-3835(00)00521-8

Nakamura, K., Izumiyama-Shimomura, N., Sawabe, M., Arai, T., Aoyagi, Y., Fujiwara, M., Tsuchiya, E., Kobayashi, Y., Kato, M., Oshimura, M., et al. 2002. Comparative analysis of telomere lengths and erosion with age in human epidermis and lingual epithelium. Journal of Investigative Dermatology. 119(5): 1014-1019. https://doi.org/10.1046/j.1523-1747. 2002.19523.x

Nasir, L., Devlin, P., Mckevitt, T., Rutteman, G., and Argyle, D.J. 2001. Telomere lengths and telomerase activity in dog tissues: a potential model system to study human telomere and telomerase biology. Neoplasia. 3(4): 351-359. https://doi.org/10.1038/sj.neo.7900173

Pestka, J.M., Schmal, H., Salzmann, G., Hecky, J., Südkamp, N.P., and Niemeyer, P. 2011. In vitro cell quality of articular chondrocytes assigned for autologous implantation in dependence of specific patient characteristics. Archives of Orthopaedic and Trauma Surgery. 131(6): 779789. https://doi.org/10.1007/s00402-010-1219-8

Pignolo, R.J., Suda, R.K., McMillan, E.A., Shen, J., Lee, S.H., Choi, Y., Wright, A.C., and Johnson, F.B. 2008. Defects in telomere maintenance molecules impair osteoblast differentiation and promote osteoporosis. Aging Cell. 7(1): 23-31. https://doi.org/10.1111/j.1474-9726.2007.00350.x

Rose, J., Söder, S., Skhirtladze, C., Schmitz, N., Gebhard, P.M., Sesselmann, S., and Aigner, T. 2012. DNA damage, discoordinated gene expression and cellular senescence in osteoarthritic chondrocytes. Osteoarthritis Cartilage. 20: 1020-1028. https://doi.org/10.1016/j.joca.2012.05.009

Sanders, J.L., Cauley, J.A., Boudreau, R.M., Zmuda, J.M., Strotmeyer, E.S., Opresko, P.L., Hsueh, W.C., Cawthon, R.M., Li, R., Harris, T.B., et al. 2009. Leukocyte telomere length is not associated with BMD, osteoporosis, or fracture in older adults: results from the health, aging and body composition study. Journal of Bone and Mineral Research . 24(9): 1531-1536. https://doi.org/ 10.1359/jbmr.090318

Shammas, M.A. 2011. Telomeres, lifestyle, cancer, and aging. Current Opinion in Clinical Nutrition and Metabolic Care. 14(1): 28-34. https://doi. org/10.1097/MCO.0b013e32834121b1

Shay, J.W., and Wright, W.E. 2000. Hayflick, his limit, and cellular ageing. Nature Reviews Molecular Cell Biology. 1: 72-76. https://doi.org/10.1038/ 35036093 
Slagboom, P.E., Droog, S., and Boomsma, D.I. 1994. Genetic determination of telomere size in humans: a twin study of three age groups. American Journal of Human Genetics. 55(5): 876-882.

Stout, G.J., and Blasco, M.A. 2013. Telomere length and telomerase activity impact the UV sensitivity syndrome xeroderma pigmentosum C. Cancer Research. 73(6): 1844-1854. https://doi.org/10.1158/0008-5472.CAN-123125

Sugimoto, M., Yamashita, R., and Ueda, M. 2006. Telomere length of the skin in association with chronological aging and photoaging. Journal of Dermatological Science. 43-47. https://doi.org/10.1016/j.jdermsci.2006. 02.004

Takasaki, T., Tsuji, A., Ikeda, N., and Ohishi, M. 2003. Age estimation in dental pulp DNA based on human telomere shortening. International Journal of Legal Medicine. 117(4): 232-234. https://doi.org/10.1007/ s00414-003-0376-5

Takubo, K., Izumiyama-Shimomura, N., Honma, N., Sawabe, M., Arai, T., Kato, M., Oshimura, M., and Nakamura, K. 2002. Telomere lengths are characteristic in each human individual. Experimental Gerontology. 37: 523-531. https://doi.org/10.1016/s0531-5565(01)00218-2

Takubo, K., Nakamura, K.I., Izumiyama, N., Furugori, E., Sawabe, M., Arai, T., Esaki, Y., Mafune, K.I., Kammori, M., Fujiwara, M., et al. 2000. Telomere shortening with aging in human liver. The Journal of Gerontology: Series A, Biological Sciences. 55(11): B533-BB536. https://doi.org/10.1093/ gerona/55.11.b533

Takubo K, N.K., Izumiyama N, Sawabe M, Arai T, Esaki Y, Tanaka Y, Mafune K, Fujiwara M, Kammori M, and Sasajima K., 1999. Telomere shortening with aging in human esophageal mucosa. Age (Omaha). 22(3): 95-99. https://doi.org/10.1007/s11357-999-0011-6

Tang, N.L., Woo, J., Suen, E.W., Liao, C.D., Leung, J.C., and Leung, P.C. 2010. The effect of telomere length, a marker of biological aging, on bone mineral density in elderly population. Osteoporosis International. 21: 8997. https://doi.org/10.1007/s00198-009-0948-4

Taylor, R.S., Ramirez, R.D., Ogoshi, M., Chaffins, M., Piatyszek, M.A., and Shay, J.W. 1996. Detection of telomerase activity in malignant and nonmalignant skin conditions. Journal of Investigative Dermatology. 106: 759-765. https://doi.org/10.1111/1523-1747.ep12345811

Thomas, P., O' Callaghan, N.J., and Fenech, M. 2008. Telomere length in white blood cells, buccal cells and brain tissue and its variation with ageing and Alzheimer's disease. Mechanisms of Ageing and Development. 129: 183190. https://doi.org/10. 1016/j.mad.2007.12.004 
Toh, W.S., Brittberg, M., Farr, J., Foldager, C.B., Gomoll, A.H., Hui, J.H., Richardson, J.B., Roberts, S., and Spector, M. 2016. Cellular senescence in aging and osteoarthritis. Acta Orthopaedica. 87: 6-14. https://doi.org/10. 1080/17453674.2016.1235087

Ueda, M., Ouhtit, A., Bito, T., Nakazawa, K., Lübbe, J., Ichihashi, M., Yamasaki, H., and Nakazawa, H. 1997. Evidence for UV-associated activation of telomerase in human skin. Cancer Research. 57(3): 370-374.

Valdes, A.M., Richards, J.B., Gardner, J.P., Swaminathan, R., Kimura, M., Xiaobin, L., Aviv, A., and Spector, T.D. 2007. Telomere length in leukocytes correlates with bone mineral density and is shorter in women with osteoporosis. Osteoporosis International. 18(9): 1203-1210. https:// doi.org/10.1007/s00198-007-0357-5

Vaziri, H., Schächter, F., Uchida, I., Wei, L., Zhu, X., Effros, R., Cohen, D., and Harley, C.B. 1993. Loss of telomeric DNA during aging of normal and trisomy 21 human lymphocytes. American Journal of Human Genetic. 52(4): 661-667.

Vleck, C.M., Haussmann, M.F., and Vleck, D. 2003. The natural history of telomeres: tools for aging animals and exploring the aging process. Experimental Gerontology. 38(7): 791-795. https://doi.org/10.1016/s05315565(03)00110-4 